\title{
Dynamics of pH, Ferrum and Mangan, and Phosphorus on Newly Opened Paddy Soil having High Soil Organic Matter on Rice Growth
}

\author{
Ladiyani Retno Widowati ${ }^{1}$ and Sukristyonubowo ${ }^{2}$ \\ ${ }^{1}$ Indonesian Soil Research Institute, Jl. Juanda No.98, Bogor, 16123, Indonesia, \\ e-mail: ladiyaniwidowati@gmail.com; ladiyaniw@yahoo.com \\ ${ }^{2}$ Indonesian Soil Research Institute, Jl. Tentara Pelajar No. 12 Cimanggu, Bogor, Indonesia, \\ e-mail: sukristiyonubowo@yahoo.com \\ Received 28 April 2011 / accepted 15 November 2011
}

\begin{abstract}
Research had been carried out at the Research and Soil Testing Laboratory and Greenhouse of Soil Research Institute, Bogor using newly opened paddy soil from Pesisir Selatan districts, West Sumatra (one year old). Total treatments tested were 12 which were combination of farmer rate, NPK recommendation $\left(1 / 2 \times ; 3 / 4 \times ; 1 \frac{1}{2} \times\right)$, straw compost $\left(1 / 2 \times ; 3 / 4 \times ; 1 \frac{1}{2} \times\right)$, and dolomite. The trial was conducted using a completely randomized design with three replications. This research had been prepared in two units, one unit for observing plant response to nutrient management and another unit for incubation trial with the same treatment placed in the greenhouse. Rice cultivar used was IR-42 in accordance to the preferred varieties of local farmers. The sampling method for measuring the solubility of $\mathrm{Fe}^{2+}$ and $\mathrm{Mn}^{2+}$, as well as the availability of $\mathrm{PO}_{4}^{3-}$ was by centrifuge $50 \mathrm{~g}$ mud samples from the incubation pots then separated clear extract using filter paper. The observation results on dynamics of $\mathrm{pH}, \mathrm{Fe}^{2+}$, $\mathrm{Mn}^{2+}$ and $\mathrm{PO}_{4}^{-3}$ mainly occured in 1 to 14 days after submerging (incubation). After 14 days soil reaction had reached thermodynamic sequence of oxidation-reduction processes, the $\mathrm{PO}_{4}^{3-}$ more available and $\mathrm{pH}$ of the soil reached the peak. The optimum dose of NPK fertilizer obtained 0.875 NPK or equal to $175 \mathrm{~kg}$ of urea, $87.5 \mathrm{~kg}$ of SP-36 and $87.5 \mathrm{~kg}$ $\mathrm{KCl} \mathrm{ha}^{-1}$. The highest number of hills achieved from straw compost treatment $1 \frac{1}{2} 2$ organic matter (OM) or 3 tons with an increase of 20\%. Application of ameliorant dolomite increased the number of tillers about 2-3\%, but insignificantly different with no dolomite treatment.
\end{abstract}

Keywords: Ferrum, mangan, paddy soil, phosphate, rice, soil pH

\section{INTRODUCTION}

Rice places a strategic position in Indonesia as staple food as well as a source of income and employment. More than $90 \%$ of the total rice is produced through irrigated rice system and the rest is produced from non-irrigated rice systems (BPS 2006). Along with the increase of (1) food demand due to increasing population, (2) the need for housing and industrial, and transportation infrastructure, (3) competition between the water requires for agriculture, industry and households, and (4) water pollution, therefore the availability of extensive irrigated rice land for rice cultivation becomes increasingly narrower and the scarce of irrigation water, which in turn decreases rice production (Baghat et al. 1996; Bouman and Tuong 2001; BPS 2002). In order to fulfill food security,

J Trop Soils, Vol. 17, No. 1, 2012: 1-8 ISSN 0852-257X increasing productivity of newly opened paddy soil should be taking into consideration. The production target is an additional two million tons per year or about $5 \%$ year $^{-1}$ to maintain national food selfsufficiency (Anonymous 2007).

Newly opened paddy soil has a morphological, chemical, physical and mineral composition depends on the characteristic of initial soil properties. Previous research reports that the submerging will cause some change in soil chemical properties. Ponnamperuma (1978) concluded that the submerging will reduce $\mathrm{Eh}$, increases and decreases $\mathrm{pH}$, and increases availability of phosphorus. This $\mathrm{P}$ element derived from the liberation of an inert $\mathrm{AlPO}_{4}\left(\mathrm{KSP}=10^{-23)}\right.$ to form $\mathrm{Al}(\mathrm{OH})_{3}$ which is more difficult to dissolve $(\mathrm{KSP}=$ $10^{-33}$ ) (Dixon et al. 1977) and it can be derived from the solubility of mineral strengit $\left(\mathrm{FePO}_{4} \cdot 2 \mathrm{H}_{2} \mathrm{O}\right)$.

Submerging of acid soil of newly opened paddy soil causes the reduction of iron $\mathrm{Fe}^{3+}$ to $\mathrm{Fe}^{2+}$ and $\mathrm{Mn}^{4+}$ to $\mathrm{Mn}^{2+}$. Soils having high Fe oxide content in the reduction environment will dissolve and harm 
to plants when the Fe content exceeds 2,000 $\mathrm{mgkg}^{-1}$ (CSAR 1993) or when the concentration of iron in the plant is more than $300 \mathrm{mg} \mathrm{kg}^{-1}$ which is the critical limit of iron toxicity to rice plant (Joseph et al. 1996; Lokossou 2006), and Sulaeman et al. (1997) found $260 \mathrm{mg} \mathrm{kg}^{-1}$ is critical limit in the soil. Other research obtained iron toxicity was appeared when the iron levels in the soil are $20-40 \mathrm{mg} \mathrm{L}^{-1}$ (van Breemen and Moorman 1978).

Soil rich in active $\mathrm{Mn}$ and organic matter will produce high $\mathrm{Mn}^{2+}$ dissolved in 1 to 2 weeks after submerging but it will decrease and stable at $10 \mathrm{mg}$ $\mathrm{kg}^{-1}$ (Randhawa et al. 1978) meanwhile the critical limit of soil Mn is 15-60 mg kg-1 (Black 1968).

Increasing rice productivity of newly opened paddy soil can be obtained by application of ameliorant such as organic matter and lime. Widowati and Rochayati (2008) have done research in South Kalimantan and concluded that ameliorants containing $\mathrm{Ca}, \mathrm{Mg}$ and micro elements, and also the addition of $\mathrm{N}, \mathrm{P}, \mathrm{K}$ and organic matter were capable to improve the productivity of the newly opened paddy soil. Based on the above background, the research was aimed to study the dynamics of $\mathrm{pH}$, Fe and $\mathrm{Mn}$, and $\mathrm{P}$ of newly opened paddy soil having high organic matter content on the rice growth, and to examine the optimum rate of inorganic fertilizer, dolomite and straw for rice growth.

\section{MATERIALS AND METHODS}

\section{Study Site}

Research had been conducted at the Research and Soil Testing Laboratory and Greenhouse of Soil Research Institute using the soil sample from newly opened paddy soil (one year old) from the Pesisir Selatan districs, West Sumatra which classified as Inceptisols (alluvial).

\section{Research Design}

Experimental design used was a Completely Randomized Design (CRD) with 3 replications, and the treatment consisted of farmer rate; four levels of $\mathrm{N}, \mathrm{P}$, and $\mathrm{K}$ fertilizer; three levels of straw compost; N, P, K fertilizer time application, and dolomite. As a base line, the treatment is illustrated at Table 1 .

Before the greenhouse experiment begin, selected initial soil characteristics were analyzed namely texture (pipette method), $\mathrm{pH}\left(\mathrm{H}_{2} 01: 2.5\right)$, organic matter, $\mathrm{N}$ (Kjeldahl method) and $\mathrm{C}$-organic (Walkley and Black method), Bray P-1 and K-exc (NH4OAc. $\mathrm{pH}$ 7.0), $\mathrm{P}$ and $\mathrm{K}$ potential ( $\mathrm{HCl} 25 \%$ extract), as well as micro-nutrient content of $\mathrm{Fe}, \mathrm{Al}$, $\mathrm{Mn}$, and Zn (DTPA extract).

After collecting soil sample from 0 to $20 \mathrm{~cm}$ soil depth, bulk soils were then homogenized and

Table 1. Treatments of the nutrient management research on newly opened paddy soil.

\begin{tabular}{|c|c|c|c|c|c|}
\hline \multirow{2}{*}{ No. Treatments } & Urea & SP-36 & $\mathrm{KCl}$ & Dolomite & Straw Compost \\
\hline & \multicolumn{3}{|c|}{................ $\mathrm{kg} \mathrm{ha}^{-1}$. } & \multicolumn{2}{|c|}{$\mathrm{Mg} \mathrm{ha}^{-1}$. } \\
\hline $\begin{array}{ll}\text { 1. } & \text { Farmers rate }(\mathrm{FR})\end{array}$ & 0 & 0 & 0 & 0 & 0 \\
\hline 2. $\mathrm{FR}+\mathrm{OM}^{*}+$ dolomite & 0 & 0 & 0 & 1 & 2 \\
\hline 3. NPK recommendations (N-rec) & 200 & 100 & 100 & 0 & 0 \\
\hline 4. NPK-rec + OM & 200 & 100 & 100 & 0 & 2 \\
\hline 5. $3 / 4$ NPK-rec + OM & 150 & 75 & 75 & 0 & 2 \\
\hline 6. $1 / 2 \mathrm{NPK}-\mathrm{rec}+\mathrm{OM}$ & 100 & 50 & 50 & 0 & 2 \\
\hline 7. $1 \frac{1}{1} / \mathrm{NPK}-\mathrm{rec}+\mathrm{OM}$ & 250 & 125 & 125 & 0 & 2 \\
\hline \multirow[t]{3}{*}{ 8. NPK-rec (NK 3 times) } & 66.7 & 100 & 33.3 & 0 & 0 \\
\hline & 66.7 & & 33.3 & 0 & 0 \\
\hline & 66.7 & & 33.3 & 0 & 0 \\
\hline \multirow{3}{*}{$\begin{array}{l}\text { 9. } \\
\text { NPK-rec }+\mathrm{OM}+\text { dolomite } \\
\text { (NK applied } 3 \text { times) }\end{array}$} & 66.7 & 100 & 33.3 & 1 & 2 \\
\hline & 66.7 & & 33.3 & 0 & 0 \\
\hline & 66.7 & & 33.3 & 0 & 0 \\
\hline 10. NPK-rec + OM + dolomite & 200 & 100 & 100 & 1 & 2 \\
\hline 11. NPK-rec + 11/2OM & 200 & 100 & 100 & 0 & 3 \\
\hline 12. NPK-rec $+1 / 2 \mathrm{PO}$ & 200 & 100 & 100 & 0 & 1 \\
\hline
\end{tabular}

*Air dry bases. 
weighed $5 \mathrm{~kg}$ per pot, submerged one day then mudded. The research had been prepared in two units, one unit for observed plant response to nutrient management and another unit for incubation trial with the same treatment placed in the greenhouse. The mudded soil for trial using plant was incubated for 7 days and planted. Rice seed "IR-42" was immerged for 14 days and then transplanted four plants per pot. At the age of 2 WAT (week after transplanting), 2 plants were thinned. Growth parameters observed were plant height and number of tillers.

Along with preparation of unit research for rice growth, also had been prepared unit incubation studies placed in adjacent. The soil in pots without plants (incubation studies) was observed intensively for the behavior of $\mathrm{pH}, \mathrm{PO}_{4}^{3-,} \mathrm{Fe}$ and $\mathrm{Mn}$ by sampling at $1,3,7,14,21,28,35$, and 42 DAT (days after transplanting). In the initial test result there was no significant difference between soil $\mathrm{pH}$ in pot with plant and $\mathrm{pH}$ in incubation studies having coefficient correlation 0.9602 , so that the soil sampling in pots without plants considered to be representative of the pots with plants. Each soil sampling, the soil in the pot was mixed uniformly then taken $\pm 50 \mathrm{~g}$ of mud into centrifuge tube and centrifuged for 10 minutes at 2,500 rpm (Gotoh and Patrick 1974; Leeper 1974). Clear extract or supernathan was separated from the soil using filter paper, then measured for Fe and Mn level by using Atomic Adsorption Spectrofotometer Varian type AA55 (AAS), available $\mathrm{P}$ (equivalent with using extract water) was measured using spectrophotometer at wavelength $636 \mathrm{~nm}$.

\section{Statistical Analysis}

Obtained data was analyzed for mean significant difference of the treatment using Anova (SPSS v.15). In order to measure the variation of the data, standard deviation was calculated and presented as error bar in the graph. Response curve of each parameter as affected by treatment was plotted in aim to illustrate the parameter dynamics in soil having high organic matter.

Table 2. Initial soil characteristics of newly opened paddy soil of the Pesisir Selatan district, West Sumatra.

\begin{tabular}{|c|c|c|c|}
\hline Parameter & Methods & Value & Criteria $^{*}$ \\
\hline Texture & Pipette & & Clay \\
\hline Sand $(\%)$ & & 4 & \\
\hline Silt $(\%)$ & & 34 & \\
\hline Clay $(\%)$ & & 63 & \\
\hline $\mathrm{pH} \mathrm{H} \mathrm{H}_{2} \mathrm{O}$ & $\mathrm{pH}$ meter & 4.68 & Acid \\
\hline $\mathrm{pH} \mathrm{KCl}$ & pH meter & 3.57 & \\
\hline $\mathrm{C}(\%)$ & Kurmies & 8.12 & Very high \\
\hline $\mathrm{N}(\%)$ & Kjehdahl & 0.44 & Medium \\
\hline $\mathrm{C} / \mathrm{N}$ & & 18 & High \\
\hline Potencial-P and $\mathrm{K}$ & $\mathrm{HCl} 25 \%$ & & \\
\hline $\mathrm{P}_{2} \mathrm{O}_{5}\left(\mathrm{mg} \mathrm{kg}^{-1}\right)$ & & 497 & High \\
\hline $\mathrm{K}_{2} \mathrm{O}\left(\mathrm{mg} \mathrm{kg}^{-1}\right)$ & & 550 & High \\
\hline Available- $\mathrm{P}_{2} \mathrm{O}_{5}\left(\mathrm{mg} \mathrm{kg}^{-1}\right)$ & Bray 1 & 6.4 & Low \\
\hline Cation exchange capacity & $\mathrm{NH}_{4} \mathrm{OAc} \mathrm{pH} 7.0$ & & \\
\hline $\mathrm{K}\left(\mathrm{Cmol}(+) 100 \mathrm{~g}^{-1}\right)$ & & 0.05 & Very Low \\
\hline $\mathrm{Ca}\left(\mathrm{Cmol}(+) 100 \mathrm{~g}^{-1}\right)$ & & 5.14 & Low \\
\hline $\operatorname{Mg}\left(\mathrm{Cmol}(+) 100 \mathrm{~g}^{-1}\right)$ & & 0.99 & Low \\
\hline $\mathrm{Na}\left(\mathrm{Cmol}(+) 100 \mathrm{~g}^{-1}\right)$ & & 0.09 & Very Low \\
\hline $\mathrm{CEC}\left(\mathrm{Cmol}(+) 100 \mathrm{~g}^{-1}\right)$ & $\mathrm{NH}_{4} \mathrm{OAc} \mathrm{pH} 7.0$ & 29.49 & High \\
\hline Base saturation (\%) & & 21 & Low \\
\hline Micro elements & DTPA extract & & \\
\hline $\mathrm{Fe}\left(\mathrm{mg} \mathrm{kg}^{-1}\right)$ & & 241.8 & Limit $260 \mathrm{mg} \mathrm{kg}^{-1}$ \\
\hline $\operatorname{Mn}\left(\mathrm{mg} \mathrm{kg}^{-1}\right)$ & & 34.7 & Limit $15-60 \mathrm{mg} \mathrm{kg}^{-1}$ \\
\hline $\mathrm{Cu}\left(\mathrm{mg} \mathrm{kg}^{-1}\right)$ & & 0.94 & \\
\hline $\mathrm{Zn}\left(\mathrm{mg} \mathrm{kg}^{-1}\right)$ & & $0: 42$ & \\
\hline
\end{tabular}

*Assessment criteria are based on the results of Soil Analysis (Balittanah 2005). 


\section{RESULTS AND DISCUSSION}

\section{Soil Characteristics}

Characteristics of soil used in the study were as follows: clay texture, acid $\mathrm{pH}$, very high $\mathrm{C}$-organic content (8.12\%), high $\mathrm{P}$ and $\mathrm{K} \mathrm{HCl} 25 \%$ content (Table 2). This soil had medium soil chemical fertility. In order to support plant growth the limiting factor should be eliminated or reduced. The main constraint was the low-available $\mathrm{K}\left(0.05 \mathrm{cmol} \mathrm{kg}^{-1}\right)$ and available iron with value $241 \mathrm{mg} \mathrm{kg}^{-1} \mathrm{Fe}$ (critical limit in soil solution is $260 \mathrm{mg} \mathrm{kg}^{-1}$, Sulaeman et al. 1997) and $34.7 \mathrm{mg} \mathrm{kg}^{-1} \mathrm{Mn}$ (critical limit in soil solution is 15$60 \mathrm{mg} \mathrm{kg}^{-1}$, Black 1968).

\section{Dynamics of Soil pH}

Soil reaction observations showed a drastic increase in the average of 1.5 units from the first week up to the third week incubations and stable at value 6.5 to 7 up to the end of incubation (Figure 1). Reduction process consumes proton, therefore

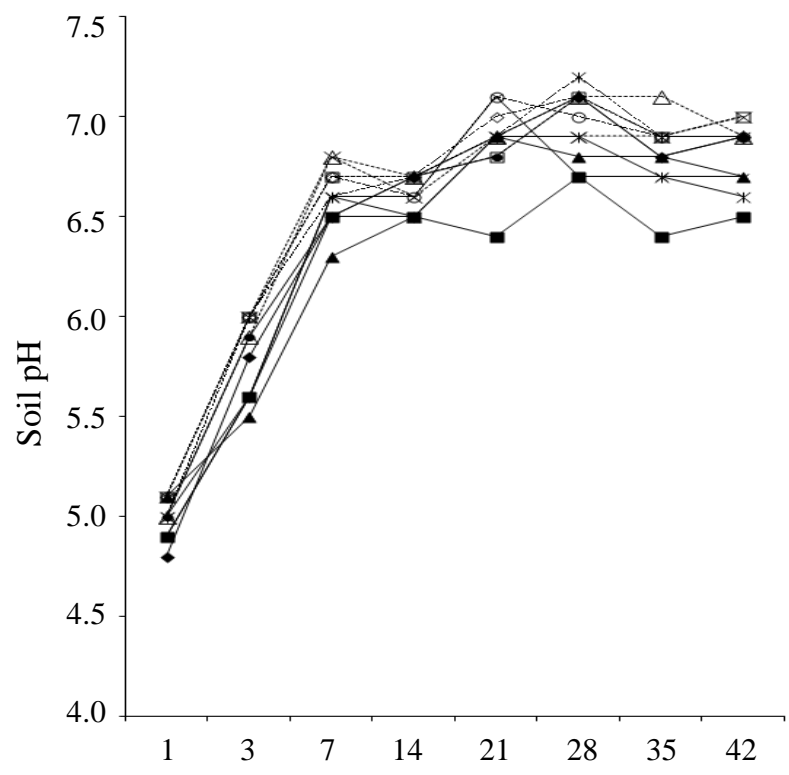

Time of observation (days)

Figure 1. Dynamics of soil $\mathrm{pH}$ with incubation time of newly opened paddy fields having high organic matter content. $--=$ Farmer rate, $\longrightarrow \mathbf{t}=$ Farmer rate $+\mathrm{OM}+$ dolomite, $* *$ NPK-rec,$*=$ NPK-rec + OM, $\multimap-=3 / 4$ NPK-rec + OM, $\multimap-1 / 2$ NPK-rec, $\cdots \cdot \cdots=11 / 4$ NPK-rec, $\cdots-\cdots=$ NPK-rec $($ NK $3 \times), \cdots \times-\cdots=$ NPK-rec + $\mathrm{OM}+$ dolomite $(\mathrm{NK} 3 \times),-\cdots-\cdots-\cdot=\mathrm{NPK}-$ rec $+\mathrm{OM}+$ dolomite, $\cdots \cdot \cdots=\mathrm{NPK}-\mathrm{rec}+$ $11 / 2 \mathrm{OM}$, and $\rightarrow--=$ NPK-rec $+1 / 2$ OM. in general soil $\mathrm{pH}$ in submerged condition will increase close to neutral. The dynamics of soil $\mathrm{pH}$ on the farmer rate did the lowest than other treatments. The low $\mathrm{pH}$ dynamics because the treatment of farmer rate was not added any fertilizer and ameliorant or it was called as control soil. According to Ritvo, et. all (2002), when an acid soil is high in reduced $\mathrm{Fe}$ form, soil $\mathrm{pH}$ will reach a neutral $\mathrm{pH}$ after few weeks submerging, this is in accordance with the observations obtained $\mathrm{pH} 7$ after two weeks incubation. Iron toxicity could occur at $\mathrm{pH}$ normal value in condition if redox potential was about 110-125 $\mathrm{mV}$ and oxygen content was bellow 3-4 $\mathrm{mg} \mathrm{L}^{-1}$ in soil having high carbon content (Audebert 2006).

\section{Dynamics of Ferrum}

Ferrum measurements at first day incubation were on average of $0.18 \mathrm{mg} \mathrm{Fe} \mathrm{L}^{-1}$ and continued to increase up to $11.1 \mathrm{mg} \mathrm{Fe} \mathrm{L}^{-1}$ at $9^{\text {th }}$ weeks incubation (Figure 2). In other words, the iron levels were are still below the critical level (20-40 $\left.\mathrm{mg} \mathrm{L}^{-1}\right)$ which could be harm to the plant. According to Tadano and Yoshida (1978), acid paddy soil rich in organic matter and high-active iron $\left(\mathrm{Fe}^{3+}\right.$ will produce high $\mathrm{Fe}^{2+}$ concentration at the first few days of flooding, then decrease and stabilize at levels of 50-100 mg kg-1 (EDTA method). The curve pattern of all treatments west almost similar as the time-incubation and there was a tendency to decrease in 42 days after incubation. Iron concentration in the soil solution which can cause iron toxicity in the soil according to some research results depends on soil $\mathrm{pH}$ (Noor and Jumberi 1998). Concentration in the soil at $100 \mathrm{mg} \mathrm{kg}^{-1} \mathrm{Fe}$ with a $\mathrm{pH}$ of 3.7 and the concentration of $300 \mathrm{mg} \mathrm{kg}^{-1} \mathrm{Fe}$ with a pH of 5.0 can be poison to the plants (Tadano and Yoshida 1978). The study of Sulaiman et al. (1997) showed the critical limit concentration of Fe (extraction of $1 \mathrm{~N} \mathrm{NH}_{4} \mathrm{OAc} \mathrm{pH} 4.8$ ) in the soil can cause iron toxicity to rice planted in the tidal area which is $260 \mathrm{mg} \mathrm{kg}^{-1} \mathrm{Fe}$, whereas the critical limit of Fe toxicity in plant tissue of rice "IR-64" is 200 $\mathrm{mg} \mathrm{kg}^{-1} \mathrm{Fe}$.

Although $\mathrm{Fe}^{2+}$ concentrations in the soil solution were still below the toxic limit, there was a tendency $\mathrm{Fe}^{2+}$ affeced the rice growth which were marked by slow growth of transplanted seedlings (10 days) and there were rust spots on older leaves. After two WAT the rice plant grew normally. Plants can grow normally because the soil redox condition of the fields reach the sequence of thermodynamics. According to Patrick and Reddy (1978), stages or sequences of reduction process has finish at an 


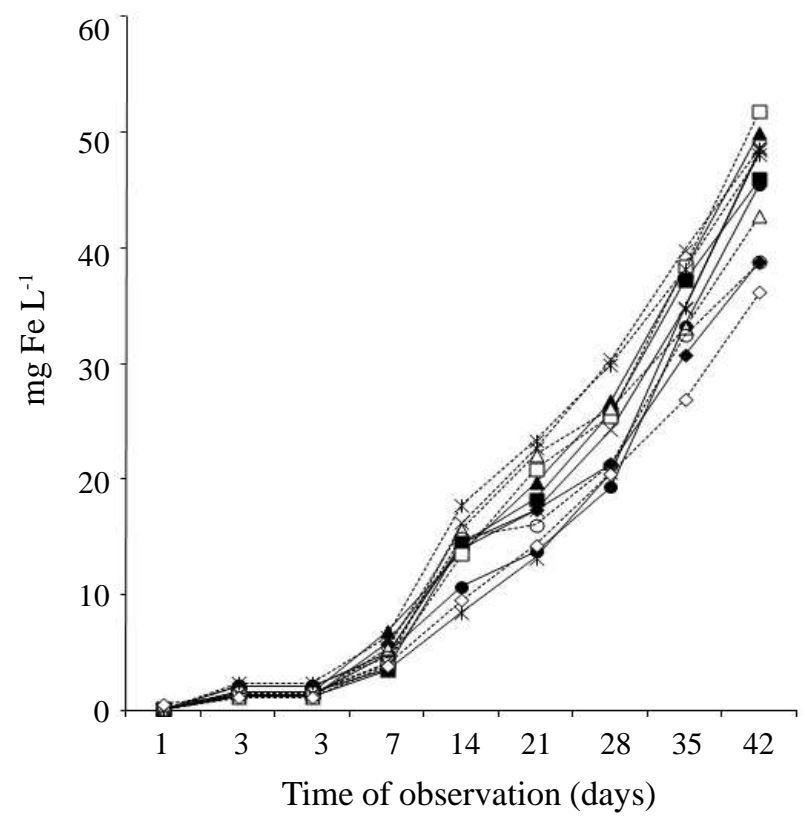

Figure 2. Fe levels in the soil solution of newly opened paddy fields having high organic matter content. $\rightarrow-=$ Farmer rate, $\longrightarrow$ $=$ Farmer rate $+\mathrm{OM}+$ dolomite,$*=$ NPK-rec , $\rightarrow-=$ NPK-rec + OM, $\rightarrow-$ $=3 / 4$ NPK-rec + OM, $\longrightarrow-1 / 2$ NPKrec, $\cdots \cdot-\cdots=11 \frac{1}{4}$ NPK-rec, $\cdots-\cdots \cdot-\cdot=$ NPK$\operatorname{rec}(\mathrm{NK} 3 \times), \cdots \times \cdots \cdot \cdots=\mathrm{NPK}-\mathrm{rec}+\mathrm{OM}+$

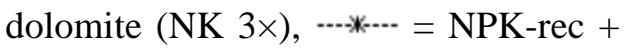
$\mathrm{OM}+$ dolomite, $\cdots \cdot \cdots=$ NPK-rec $+1 \frac{1 / 2}{2}$ $\mathrm{OM}$, and $\cdots=\mathrm{NPK}-\mathrm{rec}+1 / 2 \mathrm{OM}$.

average of 12 to 14 days after submerging. It is in accordance with the finding of this research.

\section{Dynamics of Mangan}

Dynamics of the observed Mn showed no particular pattern. At first day incubation Mn was in the average of $3.39 \mathrm{mg} \mathrm{Mn} \mathrm{L}^{-1}$ and increased to $11.1 \mathrm{mg} \mathrm{L}^{-1}$ at 2 weeks incubation, then the levels $\mathrm{Mn}$ in the solution decreased in the average of $8 \mathrm{mg}$ $\mathrm{kg}^{-1}$ up to 6 weeks. The trend was closed to the finding of van Breemen and Moorman (1978) on the solubility of $\mathrm{Mn}^{2+}$ in acid soil that is rich in active manganese and soil organic matter, the soil solution produced high soluble $\mathrm{Mn}^{2+}$ at 1-2 weeks then decreased and stabilized at level of $10 \mathrm{mg} \mathrm{kg}^{-1}$. Mn toxicity rarely occurs in lowland rice. Despite high Mn concentrations in solution, Mn toxicity is uncommon because rice is comparatively tolerant of large Mn concentrations. Rice roots are able to exclude $\mathrm{Mn}$ and rice has a high internal tolerance for high tissue Mn concentrations (Dobermann and Fairhurst 2000).

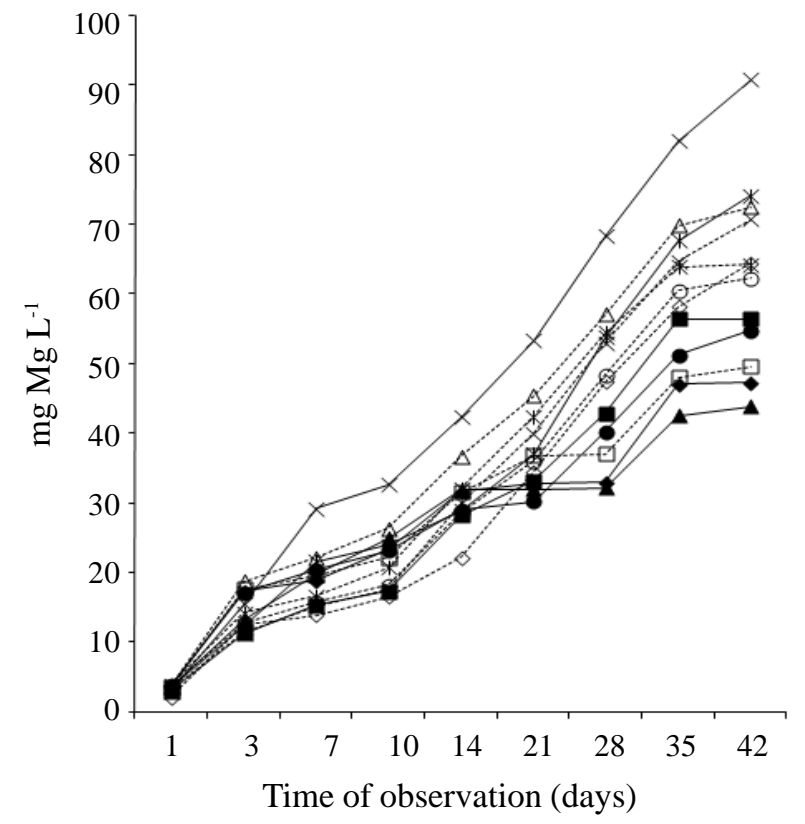

Figure 3. Cumulative levels of Mn in newly opened paddy soil having high organic matter content. $\rightarrow-=$ Farmer rate, $\longrightarrow$ Farmer rate $+\mathrm{OM}+$ dolomite, $\rightarrow *=$ NPK-rec, $\rightarrow$ * $=$ NPK-rec + OM, $\rightarrow--=$ $3 / 4$ NPK-rec + OM, $\longrightarrow=1 / 2$ NPK-rec, $\cdots \cdot \cdots=1 \frac{1}{4}$ NPK-rec, $\cdots-\cdots=$ NPK-rec $(\mathrm{NK} 3 \times), \cdots \times \cdots \cdot \cdots=\mathrm{NPK}-\mathrm{rec}+\mathrm{OM}+$ dolomite (NK 3x), ---*--- = NPK-rec + $\mathrm{OM}+$ dolomite, $\cdots \cdot \cdots=\mathrm{NPK}-\mathrm{rec}+1 \frac{1 / 2}{2}$ $\mathrm{OM}$, and $\cdots--=$ NPK-rec $+1 / 2$ OM.

To observe the effect of treatment on the levels of dissolved $\mathrm{Mn}$, the data was made in the form of cumulative (Figure 3). From the graph it can be seen that the treatment of NPK recommendation had the highest soluble Mn levels, and the treatment of Farmer rate $+\mathrm{OM}+$ dolomite had the lowest soluble Mn. Low levels of Mn in this treatment might be caused by the addition of organic fertilizer (compost straw) and dolomite which suppressed Mn solubility in water soluble form. Regarding with plant response, Shah Alam et al. (2003), reported additional $\mathrm{K}$ can partially alleviate the symptoms of Mn toxicity and Mn-induced Fe deficiency in rice seedlings and significantly improves plant growth.

\section{Dynamics of Phosphorus}

Available phosphorus increased firstly at 2 weeks incubation and then the trend was varied depending on treatment (Figure 4). The highest available phosphorus was from the treatment of $\mathrm{NPK}+\mathrm{OM}+$ dolomite. The availability of phosphorus was related to soil $\mathrm{pH}$ in which when 


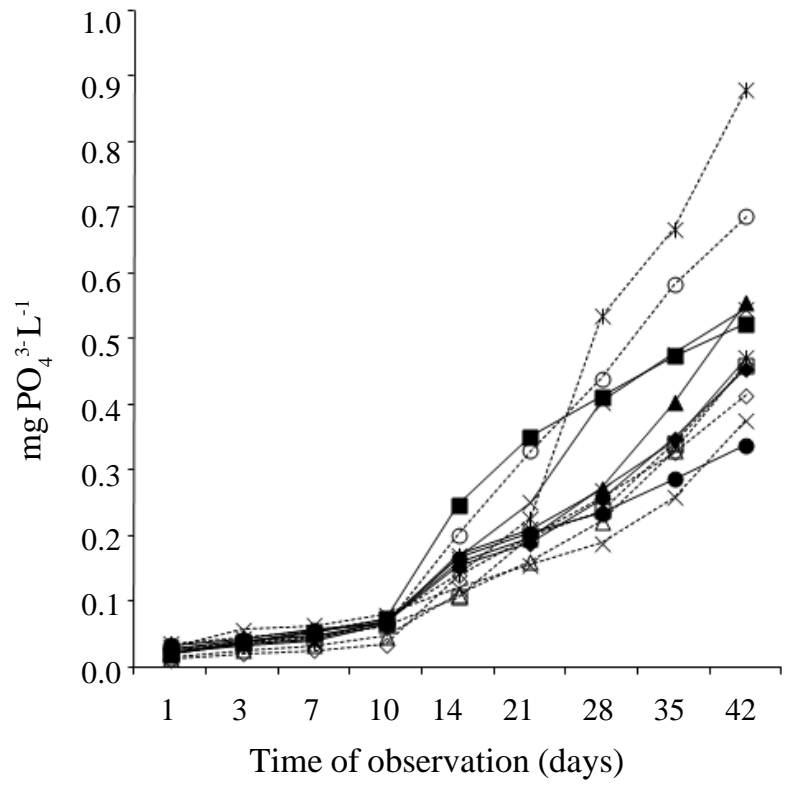

Figure 4. Cumulative levels of $\mathrm{PO}_{4}{ }^{3}$ - in the soil solution of newly opened paddy soil having high organic matter content. $\rightarrow-=$ Farmer rate, $\longrightarrow \mathbf{t}=$ Farmer rate $+\mathrm{OM}+$ dolomite, $\rightarrow$ - NPK-rec , $*=\mathrm{NPK}-\mathrm{rec}+\mathrm{OM}, \rightarrow-=3 / 4$ NPK-rec $+\mathrm{OM}, \longrightarrow=1 / 2$ NPK-rec, $\cdots \cdot \cdots=1 \frac{1}{4}$ NPK-rec, $\cdots-\cdots=$ NPK-rec $(\mathrm{NK} 3 \times), \cdots \times-\cdots=\mathrm{NPK}-\mathrm{rec}+\mathrm{OM}+$ dolomite $(\mathrm{NK} 3 \times), \cdots-\cdots-\cdots=$ NPK-rec + $\mathrm{OM}+$ dolomite, $\cdots \cdot \cdots=\mathrm{NPK}-\mathrm{rec}+1 \frac{11 / 2}{\mathrm{O}}$ $\mathrm{OM}$, and $\rightarrow-\cdots \mathrm{NPK}-\mathrm{rec}+1 / 2 \mathrm{OM}$.

soil $\mathrm{pH}$ increases and reach the peak then phosphorus is more available. Reduction of ferric form into ferrous promotes the released of soluble phosphorus into soil solution. Furthermore, an increasing of soil $\mathrm{pH}$ also causes the release of phosphorus from ferry-phosphate (Fe-P) and Al-P (Patrick and Reddy 1978). This was an evidence that the availability of phosphorus was controlled by $\mathrm{pH}$ and $\mathrm{Fe}^{2+}$ and it was started from 2 weeks incubation.

\section{Plant Growth}

The transplanted seedlings at the first week showed slow adaptation and afterwards started to grow at day $10^{\text {th }}$. This situation was different from the general rice growth on the intensified paddy fields, where at the fourth day of transplanting the seedlings started to grow (lilir). The soil produced sulfur $\left(\mathrm{H}_{2} \mathrm{~S}\right)$ and had a strong smell and also there was the presence of an oily layer from the reduced Fe at the planting time up to 10-14 DAT. After the smells and oily layer began to decrease, the rice plant showed good perform. The disappearance of

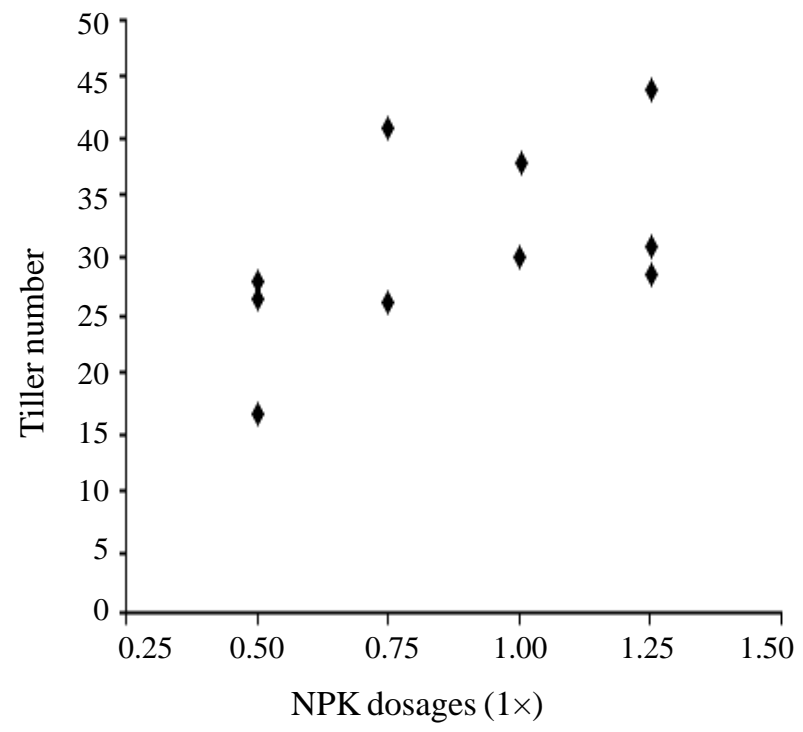

Figure 5. The influence of various dosages of NPK fertilizer to the number of tillers (NPK dosages $1 \times$ equivalent to $200 \mathrm{~kg}$ Urea, 100 $\mathrm{kg} \mathrm{SP36}$, and $100 \mathrm{~kg} \mathrm{KCl} \mathrm{ha}^{-1}$ ).

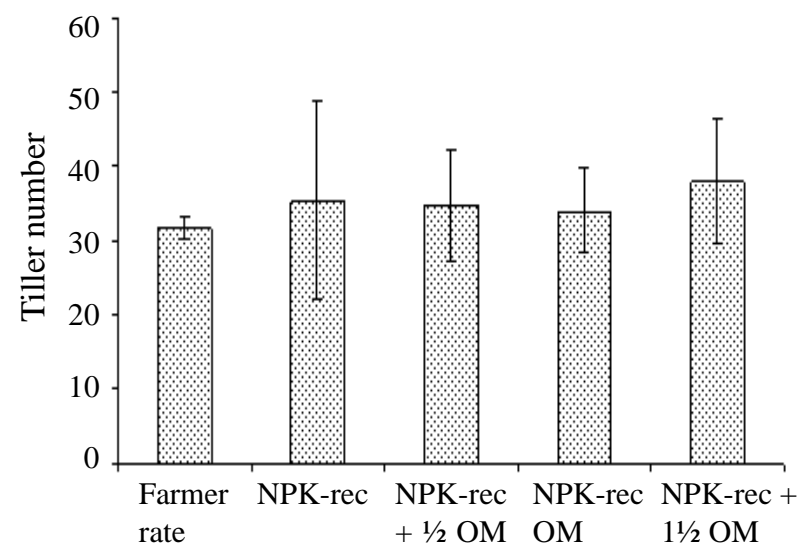

Figure 6. The number of tillers in response to straw compost rate in the research of nutrient management on newly opened paddy soil.

those matters was followed by the increasing of phosphorus availability. It can be stated that plant growth was related to the dynamics of $\mathrm{pH}, \mathrm{Fe}, \mathrm{Mn}$ and P. Generally high levels of Fe in the soil were capable to suppress Mn uptake by plants, therefore a soil having high Fe content would show minimal Mn toxicity (Todano and Yoshida 1978). Naturally rice plants also had ability to refuse Mn absorptions.

Tillers number per hills number as a response of NPK level showed that applications of $1 / 2$ NPK and $3 / 4$ NPK were inadequate for optimum growth (Figure 5). After reaching 0.875 dosage of NPK or equal to $175 \mathrm{~kg}$ of urea, $87.5 \mathrm{~kg}$ SP-36 and $87.5 \mathrm{~kg}$ of $\mathrm{KCl}$, the number of rice hills was not different with the higher rate. So that the dosage of fertilizer more than 0.875 NPK was inefficient, and over 


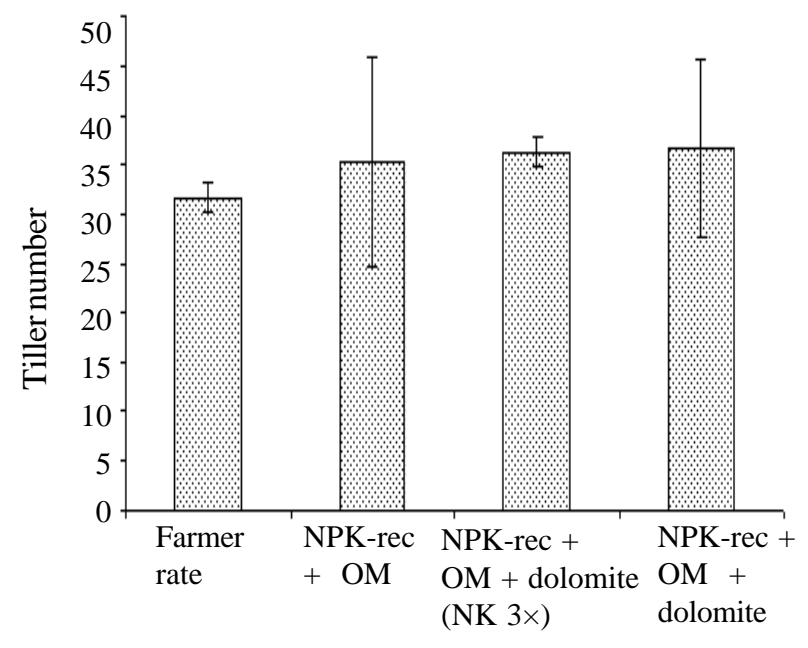

Figure 7. The number of tillers in response to dolomite application in the research of nutrient management of newly opened paddy soil.

fertilization was susceptible to contaminate agricultural environment.

To measure the influence of organic matter on plant growth, rice straw compost rate was made in three levels of $1 / 2$ dosages $\left(1 \mathrm{Mg} \mathrm{ha}^{-1}\right), 1$ dosages $\left(2 \mathrm{Mg} \mathrm{ha}^{-1}\right)$, and $1 \frac{1}{2}$ dosages $\left(3 \mathrm{Mg} \mathrm{ha}^{-1}\right)$. The number tiller of hills tended to increase but it was not significant between the dosages compared to farmers rate (Figure 6). The increments in the number of hills treatment NPK; NPK-rec + $1 / 2 \mathrm{OM}$; NPK-rec + OM, and NPK-rec + 11/2 OM, were 12, 9,7 , and $20 \%$, respectively. The lack of hills number response to the treatment rice straw compost was due to very high initial soil C-organic content (8.12\%). Application of straw compost as source organic materials was aimed in controlling the reduction level in order not to be low since the straw was organic matter having low-energy. According to Hartatik et al (2008), the application of organic matter having low-energy $(\mathrm{C} / \mathrm{N}>10)$ in the rice soil will suppress Eh value more negative. Highly reductive conditions will not provide a good environment for root growth.

The application of dolomite $(\mathrm{NPK}+\mathrm{OM}+$ dolomite) slightly increased the number of hills 2-3\% compared to the treatment of NPK-rec + OM alone (Figure 7). Dolomite served as ameliorant material by increasing soil $\mathrm{pH}$ and supplying $\mathrm{Ca}$ and $\mathrm{Mg}$. The newly opened paddy soil requires additional nutrients $\mathrm{Ca}$ and $\mathrm{Mg}$ because initial levels of those two bases were low, which is lower than critical level for optimum rice grow $(<100 \mathrm{c}$ mol Ca kg-1) (Dobermann and Fairhurst 2000). With the addition of these two bases are expected the plant more resistant to disease or harm effect of $\mathrm{Fe}$ and increased product quality, which accordance with research result of Widowati et al. (2003), on newly opened paddy soil in South Kalimantan.

\section{CONCLUSIONS}

Specific nutrient management is required on the newly opened paddy field having high organic matter content. Consideration has to be focused on $\mathrm{pH}$ stability as indicator of thermodynamic equilibrium, where it was reached at 14 days of incubation. The phosphorus availability increased after iron and mangan reached redox sequences. In order to prevent reduction process moves too low, application of low energy organic material such as rice straw compost is one alternative.

Optimum anorganic fertilizer was obtained $0.875 \mathrm{NPK}$ or equal to $175 \mathrm{~kg}$ of urea, $87.5 \mathrm{~kg}$ of SP-36 and $87.5 \mathrm{~kg} \mathrm{KCl} \mathrm{ha}^{-1}$. The anorganic fertilizer can be combined with two tons of straw compost having $20 \%$ increment, and with ameliorant dolomite having 2-3\% increment.

\section{ACKNOWLEDGEMENTS}

The research was funded by SINTA Project from Ministry of Research and Technology in collaboration with Soil Research Institute. Thanks to Linca Anggria, M.Sc. Iin Dwi Suharti, S.Si. and Marta Debora Friska for analytical assistance.

\section{REFERENCES}

Anonymous. 2007. Fertilizer recommendation N, P and $\mathrm{K}$ in paddy fields specific locations. Regulation of the Minister of Agriculture No. 40/Permentan/ OT.140/4/2007, April 11, 2007. Agency of Agriculture Research and Development. Department of Agriculture. 286 p (in Indonesian).

Audebert A. 2006. Diagnosis of risk and approaches to iron toxicity management in lowland ricw farming. In: A Audebert, LT Narte, P Kiepe, D Miller and B Beks (eds). Iron Toxicity in Rice-based System West Africa. Africa Rice Center (WARDA) 01 B.P. 2031, Cotonou, Benin, pp.6-12.

Balittanah. 2005. Manual for the Soil, Plants, Water and Fertilizers Chemistry Laboratory. In: BH Prasetyo, D Santoso and LR Widowati (eds). Indonesian Center for Agricultural Land Resources Research and Development - Indonesian Agricultural Agency for Research and Development (ICALARD IAARD), 136 p. (in Indonesian).

Bhagat RM, SI Bhuiyan and K Moody. 1996. Water, tillage and weed interactions in lowland tropical rice: a review. Agric Water Manage 31: 165-184. 
Black CA. 1968. Soil-plant Relationships. Wiley Eastern (Put.) Ltd. New Delhi.

Bouman BAM and TP Tuong. 2001. Field water management to save water and increase its productivity in irrigated lowland rice. Agric Water Manage 49: 11-30.

BPS [Badan Pusat Statistik]. 2002. Indonesia Statistics. Central Bureau of Statistics. Jakarta (in Indonesian).

BPS [Badan Pusat Statistik]. 2006. Indonesia Statistics. Central Bureau of Statistics. Jakarta (in Indonesian).

CSAR [Center of Soil and Agroclimate Research ]. 1993. Soil Survey and Research Merowi I, West Kalimantan. Agricultural Agency for Research and Development. Bogor.

Dixon JB, SB Weed, JA Kittrick, MLMirford and JL White. 1977. Minerals in Soil Environments. Soil Science Society of America, Madison, Wisconsin, USA. 948 pp.

Dobermann A and T Fairhurst. 2000. Rice: Nutrient Disorder and Nutrient Management. International Rice Research Institute - Potash and Phosphate Institute (PPI) - Potash and Phosphate Institute of Canada (PPIC). $191 \mathrm{p}$.

Gotoh S and WH Patrick Jr. 1974. Transformations of manganese in a waterlogged soil as affected by redox potential and pH. Soil Sci Soc Am Proc 36: 738-742.

Hartatik W, Sulaeman and A Kasno. 2008. Soil chemical changes and amelioration on newly opened paddy soil. In: F Agus, Wahyunto and D Santoso (eds). Newly Opened Paddy Field. Indonesian Center for Agricultural Land Resources Research and Development (ICALRRD). Agricultural Agency for Research and Development. Agriculture Department, pp. 53-76 (in Indonesian).

Joseph PA, WV Miller and MC Halbrooks. 1996. Iron toxicity stress cause Broze Speckle, a specific physiological disorder of Marigold (Tagetes erecta L.). J Am Soc Hort Sci 121 (3): 430-437.

Leeper GW. 1974. The forms and reactions of manganese in the soil. Soil Sci 63: 79-94.

Lokossou B. 2006. Evaluating iron toxicity on rice production in Lotodenou in Southern Benin. In: . Audebert, LT Narte, P Kiepe, D Miller and B Beks (eds). Iron Toxicity in Rice-based System West Africa. Ap. 125-132.

Noor A and A Jumberi. 1998. The role of ameliorant materials, potassium fertilizer and varieties to overcome iron toxicity in rice plants on tidal land. In: Workshop proceedings on Agricultural Development Strategy Kalimantan Region, 2-3 December 1997 in Banjarbaru. Agricultural Research Agency. Installation Research and Assessment of Agricultural Technology Banjarbaru. pp. 275-279 (in Indonesian).
Patrick WH Jr and CN Reddy. 1978. Chemical changes in rice soils. In: Soil and Rice. IRRI. Los Baños. Philippines, pp. 361-379.

Ponnamperuma FN. 1978. Electrochemical changes in submerged soil and the growth of rice. In: Soil and Rice. IRRI. Los Baños, Philippines. pp. 421-444.

Randhawa NS, MK Sinha and PN Takkar. 1978. Micronutrient. p. 581-603. In: Soil and Rice. IRRI, Los Banos, Philippines.

Ritvo G, Y Afnimelech and M Kochba. 2002. Empirical relationship between conventionally determined $\mathrm{pH}$ and in situ value in waterlogged soils. Aquac Eng 27 (1): 1-8.

Shah Alam, S Kamei and S Kamai. 2003. Amelioration of manganese toxicity in young rice seedling with potassium. J Plant Nut 26 (6): 1301-1314. doi: 10.1081/PLN-120020372.

Sulaeman, Eviati and JS Adiningsih. 1997. The influence of Eh and $\mathrm{pH}$ influence on phosphate adsorption characteristics, the solubility of iron and other nutrients in the soil Hapludox Lampung. In: U Kurnia, Sukarman, O Harijaja, DD Tarigan, F Agus, N Suharta, DA Suriadikarta. Proceeding of Meeting and Discussion and Communication Research Soil and Agro-climate. Section: Chemistry and Soil Biology. Cisarua, Bogor 4-6 March 1997. Center for Soil and Agroclimate Research, Bogor, pp. 118 (in Indonesian).

Sulaiman, AArifin and G Nohoi. 1997. Correlation studies on rice growth with soil iron. J Kalimantan Agric 2 (4): 1-14 (in Indonesian).

Tadano $\mathrm{T}$ and S Yoshida. 1978. Chemical changes in submerged soils and their effect on rice growth. In: Soil and Rice. IRRI. Los Baños. Philippine, pp. 399 420.

van Breemen N and FR Moorman. 1978. Iron-toxic soils. In: Soil and Rice. IRRI, Los Baños, Philippines. p. 781-797.

Widowati LR and S Rochayati. 2008. Nutrient management to improve rice productivity of newly opened paddy soil in Harapan Masa- Tapin In South Kalimantan. Paper presented at the National Seminar of BBSDLP, 25-27 November 2008. 13 p (in Indonesian).

Widowati LR, Kencanasari A, S Widati, Maryam and S Rochayati. 2003. Calcium and magnesium fertilization on acid paddy soil in Central Lampung. In: Proceedings of National Symposium on Utilization of Acid Soils. Indonesian Soil Research Institute. Bogor (in Indonesian).

Yusuf AD, Syamsudin, G Satari and S Djakasutami. 1990. The influence of $\mathrm{pH}$ and Eh of the solubility of Fe, $\mathrm{Al}$ and Mn on newly opened paddy soil on Sitiung Oxisol. Rice Management Proceeding Support the food self-sufficient and Transmigration Program: Prospects and Problems, pp. 237-269 (in Indonesian). 